\title{
AKTIVITAS EKSTRAK RIMPANG TEMULAWAK (Curcuma xanthorrhiza Roxb.) PADA RADIAL ARM MAZE DAN PASIVE AVOIDANCE TEST TIKUS MODEL DEMENSIA
}

\section{ACTIVITY OF Curcuma xanthorrhiza Roxb. EXTRACT TO RADIAL ARM MAZE AND PASIVE AVOIDANCE TEST ON DEMENTIA MODEL OF RAT}

\author{
Didik Yuni Prasetya, Sapto Yuliani \\ Fakultas Farmasi Universitas Ahmad Dahlan \\ Jl. Prof Dr. Soepomo, Janturan, Yogyakarta \\ Email: didix.prazetya@yahoo.com
}

\begin{abstract}
ABSTRAK
Temulawak (Curcuma xanthorrhiza Roxb.) merupakan tanaman yang mengandung kurkumin. Kurkumin terbukti mengurangi kerusakan oksidatif dan defisit memori yang terkait dengan penuaan. Penelitian ini bertujuan untuk mengetahui aktifitas ekstrak etanol rimpang temulawak terhadap fungsi memori melalui pengamatan uji radial arm maze dan passive avoidance test pada tikus model demensia yang diinduksi trimetiltin. Penelitian ini memakai rancangan post test controlled design menggunakan 42 ekor tikus yang terbagi menjadi 6 kelompok, masing-masing kelompok terdiri dari 7 ekor tikus. Kelompok I (kontrol sehat) diberi larutan CMC-Na 0,5 \% secara oral. Kelompok II (kontrol negatif) diberi larutan CMC-Na 0,5 \% secara oral. Kelompok III, IV, dan V diberi ekstrak temulawak masing-masing 120 mg/kgBB, $240 \mathrm{mg} / \mathrm{kgBB}$, dan $480 \mathrm{mg} / \mathrm{kgBB}$ secara oral. Kelompok VI (kontrol positif) diberi larutan pirasetam $500 \mathrm{mg} / \mathrm{kgBB}$ secara intraperitoneal. Semua kelompok diberi trimetiltin secara intraperitoneal kecuali kelompok I. Data uji memori diperoleh melalui uji maze radial dan uji menghindar pasif. Data uji maze radial dianalisis dengan Anova dilanjutkan dengan uji LSD, sedangkan data uji menghindar pasif dianalisis dengan uji Kruskal Wallis dilanjutkan dengan uji Mann-Whitney. Ekstrak etanol rimpang temulawak (Curcuma xanthorrhiza Roxb.) dapat mencegah penurunan fungsi memori tikus Wistar yang diinduksi trimetiltin . Dosis 240 mg/kgBB menunjukkan angka kesalahan paling kecil pada uji radial arm maze , namun dosis $120 \mathrm{mg} / \mathrm{kgBB}, 240 \mathrm{mg} / \mathrm{kgBB}$ dan $480 \mathrm{mg} / \mathrm{kgBB}$ semuanya menunjukkan waktu retensi yang lebih besar pada uji passive avoidance.
\end{abstract}

Kata kunci : Curcuma xanthorrhiza Roxb, memori, maze radial, menghindar pasif

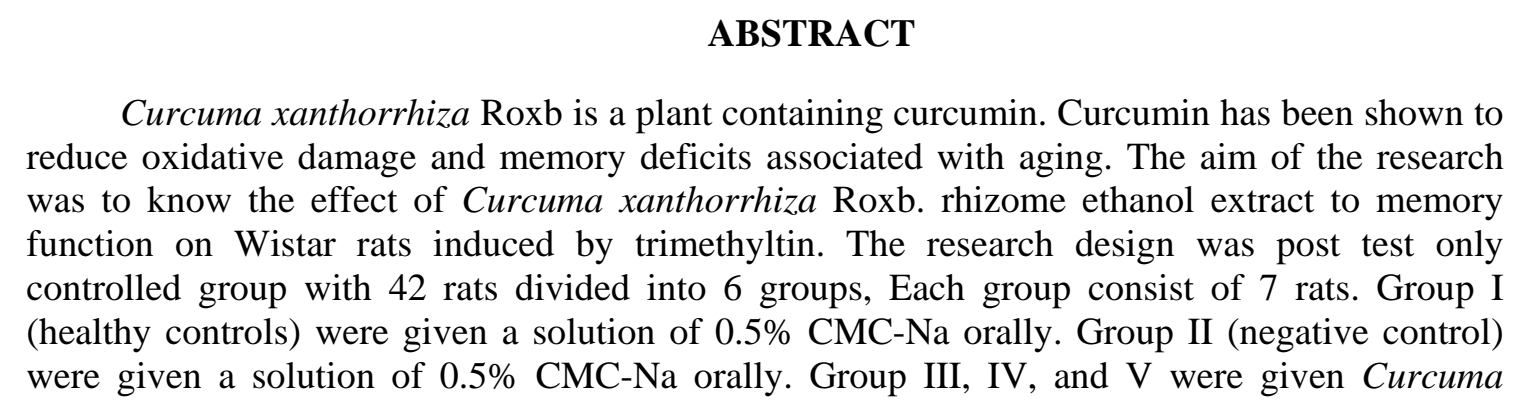


xanthorrhiza Roxb. extract each $120 \mathrm{mg} / \mathrm{kgBW}, 240 \mathrm{mg} / \mathrm{kgBW}$, and $480 \mathrm{mg} / \mathrm{kgBW}$ orally. Group VI (positive control) were given piracetam $500 \mathrm{mg} / \mathrm{kgBW}$ intraperitoneally. All groups were given trimethyltin intraperitoneally except group I. Data indicating memory function were obtained from radial maze test and passive avoidance test. Radial maze test data were analyzed by ANOVA followed by LSD test, while the passive avoidance test data were analyzed with the Kruskal Wallis test followed by Mann-Whitney test. In conclusion, ethanol extract of temulawak rhizome (Curcuma xanthorrhiza Roxb) at doses of $120 \mathrm{mg} / \mathrm{kgBW}, 240 \mathrm{mg} / \mathrm{kgBW}$ and $480 \mathrm{mg} / \mathrm{kgBW}$ can prevent memory function decline on Wistar rats induced by trimethyltin.

Key words: Curcuma xanthorrhiza Roxb., memory, radial maze, passive avoidance

\section{PENDAHULUAN}

Demensia merupakan istilah umum yang menggambarkan berbagai penyakit dan kondisi yang berkembang ketika sel-sel saraf di otak mati atau fungsi tidak lagi normal. Kematian atau kerusakan sel-sel saraf menyebabkan perubahan dalam memori seseorang, perilaku, dan kemampuan untuk berpikir jernih (Anonim, 2012). Hampir seluruh pasien demensia menunjukkan gangguan memori pada awal gejala timbulnya penyakit (Strub et al., 2000). Stres

oksidatif merupakan patogenesis penting dalam perkembangan demensia (Butterfield et al., 2002). Radikal bebas dapat menyebabkan peroksidasi lipid, oksidasi protein, perubahan spesies oksigen reaktif (ROS), dan akhirnya menyebabkan kematian neuron otak (Varadarajan et al., 2000). Hal ini tidak mengherankan karena otak lebih rentan terhadap kerusakan oksidatif dibanding organ atau jaringan lain, karena tingkat tinggi dari konsumsi oksigen, kandungan lemak tak jenuh ganda yang tinggi, dan relatif kurangnya enzim antioksidan (Musalmah et al., 2009).

Temulawak (Curcuma xanthorrhiza Roxb.) merupakan salah satu tanaman obat yang banyak digunakan sebagai bahan baku dalam industri jamu dan farmasi. Beberapa penelitian yang telah dilakukan menemukan bahwa di dalam temulawak terdapat senyawa kurkuminoid yang diketahui mempunyai aktivitas antioksidan (Nurcholis et al., 2012). Kurkumin berfungsi untuk mengurangi kerusakan oksidatif dan defisit memori yang terkait dengan penuaan. Secara khusus, kurkumin telah terbukti mengurangi kerusakan oksidatif dan patologi amiloid pada demensia Alzheimer (Frautschy et al., 2001). Penelitian ini bertujuan untuk mengetahui efek ekstrak etanol rimpang temulawak (Curcuma xanthorrhiza Roxb) terhadap fungsi memori Wistar yang diinduksi trimetiltin.

\section{METODE PENELITIAN}

\section{Alat}

Alat yang digunakan dalam pembuatan serbuk rimpang temulawak adalah pisau, oven, mesin giling, dan ayakan ukuran 40 mesh. Alat yang digunakan dalam pembuatan ekstrak etanol rimpang temulawak adalah toples, alat-alat gelas, stirrer, rotary evaporator merek Heidolph, plastik, kain flanel, dan timbangan analitik merek Ohaus. Alat yang digunakan dalam standarisasi ekstrak adalah alat-alat gelas dan densitometer merek Camag. Pada uji fungsi memori alat yang digunakan adalah alat uji menghindar pasif modifikasi Jarvix (Herlina, 2010), radial maze 8 lengan, kandang tikus, alat-alat gelas, timbangan analitik, alat suntik, dan jarum oral.

\section{Bahan}

Bahan yang digunakan dalam penelitian ini adalah rimpang temulawak yang diperoleh dari daerah Samigaluh, Kulon Progo, tikus 
jantan galur Wistar dengan berat badan 150200 gram dan berumur kurang lebih 2-3 bulan diperoleh dari Laboratorium Farmakologi Fakultas Farmasi Universitas Gajah Mada, Yogyakarta, fase diam silica gel 60 F 254, fase gerak kloroform dan methanol, etanol 80\%, trimetiltin (TMT) dari Sigma, corn oil (Tropicana), CMC-Na (NatriumCarboxymethyle Cellulose) $\quad 0,5 \%$ dan pirasetam dari PT Hexpharm Jaya Laboratories.

\section{Jalannya Penelitian}

\section{Pembuatan ekstrak}

Rimpang temulawak dicuci lalu diiris setebal 6-7 $\mathrm{mm}$ dan dioven pada suhu $50{ }^{\circ} \mathrm{C}$ sampai kadar air di bawah $10 \%$. Simplisia kering digiling dan diayak dengan ayakan 40 mesh. Sebanyak 250 gram serbuk kering direndam dengan etanol $80 \%$ sebanyak 1000 $\mathrm{ml}$ dan selama perendaman dilakukan pengadukan mengguna-kan stirrer selama 4 jam dan didiamkan selama 24 jam.

Maserat disaring dan sari etanol diuapkan hingga berbentuk ekstrak kental. Ekstrak yang diperoleh distandardisasi terhadap kadar kurkuminnya. Standardisasi ekstrak diawali dengan pembuatan standar kurkumin $1 \mathrm{mg} / \mathrm{ml}$, pembuatan kurva baku $(0,05 ; \quad 0,1 ; \quad 0,2 ; \quad 0,4 ; 0,8) \quad \mathrm{mg} / \mathrm{ml} \quad$ dan pembuatan sampel dengan cara melarutkan $100 \mathrm{mg}$ ekstrak dalam $10 \mathrm{ml}$ etanol 96\% kemudian ditotolkan pada plate KLT dan dielusi. Fase diam yang digunakan adala Silika Gel 60 F 254 sedangkan fase geraknya adalah campuran kloroform dan metanol dengan perbandingan $\quad 9: 1$.

\section{Uji Farmakologi}

Hewan uji dibagi menjadi enam kelompok, masing-masing kelompok terdiri dari 7 ekor tikus. Kelompok I (kontrol sehat) dan kelompok II (kontrol negatif) diberi larutan CMC-Na $0,5 \%$ secara peroral. Kelompok III diberi suspensi ekstrak etanol rimpang temulawak dengan dosis 120
mg/kgBB secara peroral. Kelompok IV diberi suspensi ekstrak etanol rimpang temulawak dengan dosis $240 \mathrm{mg} / \mathrm{kgBB}$ secara peroral. Kelompok $\mathrm{V}$ diberi suspensi ekstrak etanol rimpang temulawak dengan dosis 480 $\mathrm{mg} / \mathrm{kgBB}$ secara peroral dan kelompok VI (kontrok positif) diberi larutan pirasetam dengan dosis $500 \mathrm{mg} / \mathrm{kgBB}$ secara intraperitoneal. Perlakuan dilakukan selama 8 hari, lalu pada hari ke-9 dilakukan uji belajar. Setelah itu tikus diberi suntikan TMT 12 $\mathrm{mg} / \mathrm{kgBB}$ secara intraperitoneal kecuali kelompok I kemudian tikus dimasukkan ke kandang dan setelah 24 jam dilakukan uji retensi dilanjutkan dengan uji maze radial.

\section{Uji menghindar pasif}

Alat yang digunakan adalah alat uji menghindar pasif modifikasi dari Jarvik. Alat ini terdiri dari 2 ruangan, ruang kecil dan ruang besar. Ruang kecil $(30 \times 40 \mathrm{~cm})$ transparan dan diterangi dengan lampu 25 Watt setinggi $50 \mathrm{~cm}$ dari lantai yang terbuat dari besi yang disusun paralel. Ruang besar berupa kamar gelap berukuran $50 \times 50 \times 50$ $\mathrm{cm}$ yang berlantai dari besi yang disusun paralel berjarak $1 \mathrm{~cm}$ antar sesamanya yang dialiri arus listrik $5 \mathrm{~mA}$. Kedua ruangan dihubungkan dengan sebuah pintu kecil (15 cm tinggi, $20 \mathrm{~cm}$ lebar).

Pengukuran terdiri dari uji belajar dan uji retensi. Uji belajar dilakukan pada hari ke9 sedangkan uji retensi dilakukan pada hari ke-10. Tikus yang akan diukur perilakunya diletakkan dalam ruangan terang dan secara pasif diharapkan akan memasuki ruang gelap lewat pintu penghubung dan segera setelah masuk ke kamar gelap kakinya dikejutkan dengan arus listrik lemah yang dialirkan ke lantainya. Waktu yang dibutuhkan tikus mulai dimasukkan di ruang terang sebelum pemberian TMT sampai tikus masuk ke dalam ruang gelap dicatat sebagai waktu belajar. Tikus diberi suntikan TMT dan pada hari ke10 dilakukan uji retensi. Cara uji retensi sama dengan uji belajar. Waktu maksimal dalam pengukuran ini adalah 600 detik. Variabel 
yang menggambarkan kemampuan fungsi memori adalah lama retensi yaitu selisih RTLT (Retention Time-Latency Time).

\section{Uji maze radial 8 lengan}

Maze radial yang digunakan pada penelitian ini terdiri dari papan yang terletak di sentral dengan delapan lengan yang tersusun radial mengelilingi papan di tengah. Diameter tengah maze $36 \mathrm{~cm}$, panjang masing-masing lengannya $80 \mathrm{~cm}$ dan tinggi lengan $20 \mathrm{~cm}$. Maze terbuat dari bahan transparan untuk memudahkan tikus melihat dan mengingat keadaan di luar maze.

Pada hari ke-7 sampai ke-9, tikus diadaptasikan terhadap alat maze radial 8 lengan. Pada hari ke-7, tikus diletakkan di bagian tengah lempeng maze radial untuk menerima penyesuaian selama 10 menit dengan lengan tidak diberi umpan. Selanjutnya tikus setiap hari hanya diberi makan 5 gram pelet tetapi tetap diberi minum. Hari ke-8 dan ke-9 tikus dibiarkan di bagian tengah lempeng selama 10 menit, masingmasing lengan diberi umpan pada pintu masuk, bagian tengah dan ujung lengan maze pada hari ke-8 dan umpan diletakkan pada bagian tengah dan ujung lengan maze pada hari ke-9. Pada hari ke-10 dilakukan uji kinerja maze radial 8 lengan.

Untuk mengukur fungsi memori dari semua tikus, digunakan alat uji maze radial 8 lengan. Ujung masing-masing lengan diletakkan cangkir (diameter 2,5 cm dan tinggi $2 \mathrm{~cm}$ ) berisi pelet segar (100 mg).

Seluruh lengan diberi umpan. Pada waktu uji kinerja maze radial, tikus diletakkan di dalam lempeng silindris dengan arah berlawanan dengan peneliti dan tikus dibiarkan beradaptasi selama 30 detik dengan pintu gerbang tertutup. Setelah periode penyesuaian, pintu gerbang diangkat sehingga tikus bebas bergerak di segala tempat di maze. Sesi diakhiri setelah tikus mengonsumsi pelet di seluruh lengan atau setelah memakan waktu 10 menit. Kinerja maze radial ditentukan menurut angka kesalahan tikus dalam memasuki lengan maze radial 8 lengan.

\section{Analisis Data}

Data uji menghindar pasif yaitu lama retensi dianalisis dengan uji Kruskal Wallis dilanjutkan dengan uji Mann-Whitney sedangkan data uji maze radial yaitu angka kesalahan dianalisis dengan Anova dilanjutkan dengan uji LSD.

\section{HASIL DAN PEMBAHASAN}

\section{Hasil pembuatan ekstrak}

Pembuatan ekstrak etanol rimpang temulawak dilakukan di laboratorium Fitokimia Fakultas Farmasi Universitas Ahmad Dahlan. Ekstrak diperoleh dari 850 gram serbuk kering rimpang temulawak yang diekstraksi dengan pelarut etanol $80 \%$ sehingga diperoleh ekstrak kental etanol $80 \%$ rimpang temulawak sebanyak 221 gram atau $26,00 \%$. Secara organoleptis ekstrak yang diperoleh berwarna coklat gelap, kental serta mempunyai bau khas. Hasil standarisasi menunjukkan bahwa kurkumin yang terkandung dalam ekstrak sebesar 16,40\%.

\section{Hasil uji fungsi memori}

Fungsi memori pada penelitian ini diukur menggunakan 2 macam uji yaitu uji menghindar pasif dan uji maze radial. Hasil uji menghindar pasif berupa rerata lama retensi tikus dapat dilihat pada Tabel I dan Gambar 1. Sedangkan hasil uji maze radial berupa angka kesalahan tikus dalam memasuki lengan maze radial 8 lengan dapat dilihat pada Tabel II dan Gambar 2.

Analisis statistika data lama retensi tikus terdistribusi tidak normal dan tidak homogen $(\mathrm{p}<0,05)$. Hasil uji Kruskal Wallis menunjukkan bahwa terdapat perbedaan bermakna rerata lama retensi tikus diantara ke enam kelompok dengan $\mathrm{p}=0,001 \quad(\mathrm{p}<0,05)$, selanjutnya dilakukan uji Mann-Whitney untuk membandingkan perbedaan lama retensi antar kelompok sedangkan analisis statistika data angka kesalahan tikus dalam memasuki lengan maze pada terdistribusi normal dan 
homogen ( $>00,05)$. Pada uji Anova diperoleh nilai $\mathrm{p}=0,000(\mathrm{p}<0,05)$, yang berarti terdapat perbedaan bermakna angka kesalahan tikus antar kelompok. Untuk mengetahui perbedaan angka kesalahan tikus tiap kelompok dilakukan uji LSD.

Hasil uji Mann-Whitney lama retensi tikus pada uji menghindar pasif menunjukkan perbedaan signifikan antara kelompok II dengan kelompok I yang menunjukkan pemberian TMT $12 \mathrm{mg} / \mathrm{kgBB}$ dapat menurunkan fungsi memori tikus. Menurut Shuto et al., (2009) pemberian trimetiltin dapat menyebabkan degenerasi saraf dalam otak tikus melalui mekanisme stres oksidatif. Hippocampus merupakan target selektif toksisitas TMT (Martin et al., 2000) sehingga bila terjadi kematian sel-sel neuron pada hippocampus dapat menyebabkan kelema han memori (Colville dan Bassert, 2002), namun berdasarkan hasil uji LSD angka kesalahan tikus dalam memasuki lengan maze pada uji maze radial, tidak menunjukkan perbedaan signifikan antara kelompok II dengan kelompok I, yang berarti pemberian TMT 12 $\mathrm{mg} / \mathrm{kgBB}$ tidak menurunkan fungsi memori tikus. Hal ini mungkin disebabkan waktu pengujian yang dilakukan siang hari sedangkan tikus merupakan hewan nocturnal yang mencari makan di malam hari sehingga mempengaruhi hasil penelitian ini.
Selain itu, menurut Narwanto et al. (2008), pengamatan pada maze radial dilakukan selama 12 hari, akan tetapi pengamatan pada penelitian ini hanya dilakukan selama 1 hari sehingga belum terlihat penurunan fungsi memori tikus dan data yang diperoleh dari uji maze radial ini tidak bisa digunakan untuk pengambilan kesimpulan tentang efek ekstrak rimpang temulawak terhadap fungsi memori tikus Wistar yang diinduksi trimetiltin. Oleh karena itu, data yang digunakan untuk pengambilan kesimpulan adalah data dari hasil uji menghindar pasif.

Hasil uji Mann-Whitney lama retensi tikus pada uji menghindar pasif juga menunjukkan perbedaan signifikan antara kelompok II dengan kelompok VI yang menunjukkan pemberian pirasetam 500 $\mathrm{mg} / \mathrm{kgBB}$ dapat mencegah penurunan fungsi memori tikus yang diakibatkan oleh TMT. Pencegahan penurunan fungsi memori ini sejalan dengan mekanisme kerja dari pirasetam diantaranya sebagai neuroprotektif dan pencegah kematian neuron oleh radikal bebas (Winblad, 2005).

Perbedaan signifikan lama retensi tikus pada uji menghindar pasif juga terlihat antara kelompok II dengan kelompok III, kelompok $\mathrm{IV}$, dan kelompok $\mathrm{V}$ yang menunjukkan bahwa pemberian ekstrak etanol rimpang temulawak pada dosis $120 \mathrm{mg} / \mathrm{kgBB}, 240$ $\mathrm{mg} / \mathrm{kgBB}, 480 \mathrm{mg} / \mathrm{kgBB}$ dapat mencegah penurunan fungsi memori tikus.

Tabel I. Waktu belajar (LT), waktu retensi (RT) dan lama retensi (RT-LT) tikus (rerata \pm SEM)

\begin{tabular}{lcll}
\hline \multicolumn{1}{c}{ Kelompok Perlakuan } & \multicolumn{1}{c}{ LT (detik) } & \multicolumn{1}{c}{ RT (detik) } & \multicolumn{1}{c}{ RT-LT (detik) } \\
\hline Kontrol sehat & $16,43 \pm 2,39$ & $600,00 \pm 0,00$ & $583,57 \pm 2,39^{\mathbf{b}}$ \\
Kontrol negatif & $20,71 \pm 1,76$ & $174,14 \pm 68,04$ & $153,43 \pm 68,47^{\mathbf{a}}$ \\
Ekstrak 120 mg/kgBB & $7,00 \pm 0,95$ & $600,00 \pm 0,00$ & $578,71 \pm 13,98^{\mathbf{b}}$ \\
Ekstrak $240 \mathrm{mg} / \mathrm{kgBB}$ & $6,43 \pm 1,43$ & $600,00 \pm 0,00$ & $593,57 \pm 1,43^{\mathbf{b}}$ \\
Ekstrak 480 mg/kgBB & $3,14 \pm 0,14$ & $578,57 \pm 13,60$ & $575,43 \pm 13,80^{\mathbf{b}}$ \\
Kontrol positif & $5,14 \pm 0,91$ & $544,14 \pm 36,66$ & $539,00 \pm 37,01^{\mathbf{b}}$ \\
\hline
\end{tabular}

Keterangan: Tanda $\left(^{\mathbf{a}}\right)$ menunjukkan perbedaan bermakna terhadap kelompok kontrol sehat, tanda $\left({ }^{\mathbf{b}}\right)$ menunjukkan perbedaan bermakna terhadap kelompok kontrol negatif $(\mathrm{p}<0,05)$ 


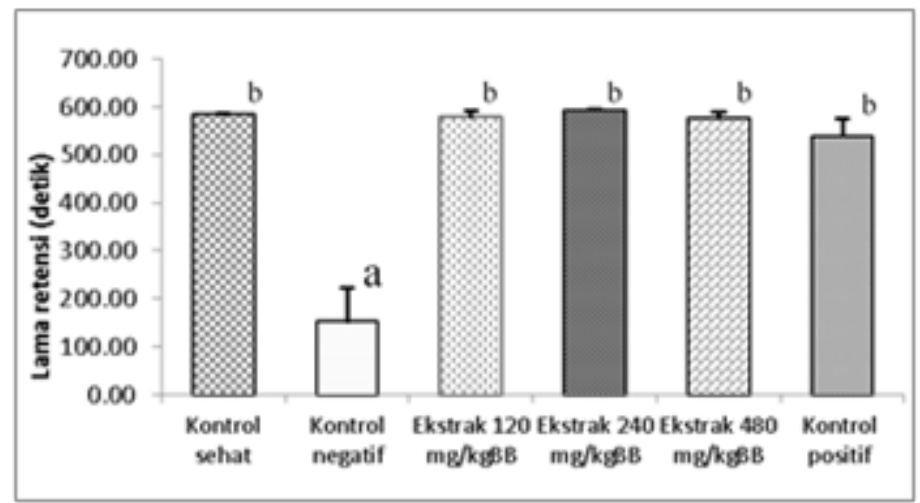

Gambar 1. Histogram lama retensi tikus

Keterangan: Tanda $\left({ }^{\mathrm{a}}\right)$ menunjukkan perbedaan bermakna terhadap kelompok kontrol sehat, tanda $\left({ }^{\mathbf{b}}\right)$ menunjukkan perbedaan bermakna terhadap kelompok kontrol negatif $(\mathrm{p}<0,05$

\section{Tabel II. Angka kesalahan tiap kelompok dalam memasuki lengan maze}

\begin{tabular}{lc}
\hline Kelompok perlakuan & Angka kesalahan (rerata \pm SEM) \\
\hline Kontrol sehat & $0,53 \pm 0,05$ \\
Kontrol negatif & $0,70 \pm 0,08$ \\
Ekstrak $120 \mathrm{mg} / \mathrm{kgBB}$ & $0,32 \pm 0,07^{*}$ \\
Ekstrak $240 \mathrm{mg} / \mathrm{kgBB}$ & $0,17 \pm 0,07^{*}$ \\
Ekstrak $480 \mathrm{mg} / \mathrm{kgBB}$ & $0,34 \pm 0,09^{*}$ \\
Kontrol positif & $0,31 \pm 0,08^{*}$ \\
\hline
\end{tabular}

Keterangan: Tanda ( $\left.{ }^{*}\right)$ menunjukkan perbedaan bermakna terhadap kelompok kontrol negatif $(\mathrm{p}<0,05)$

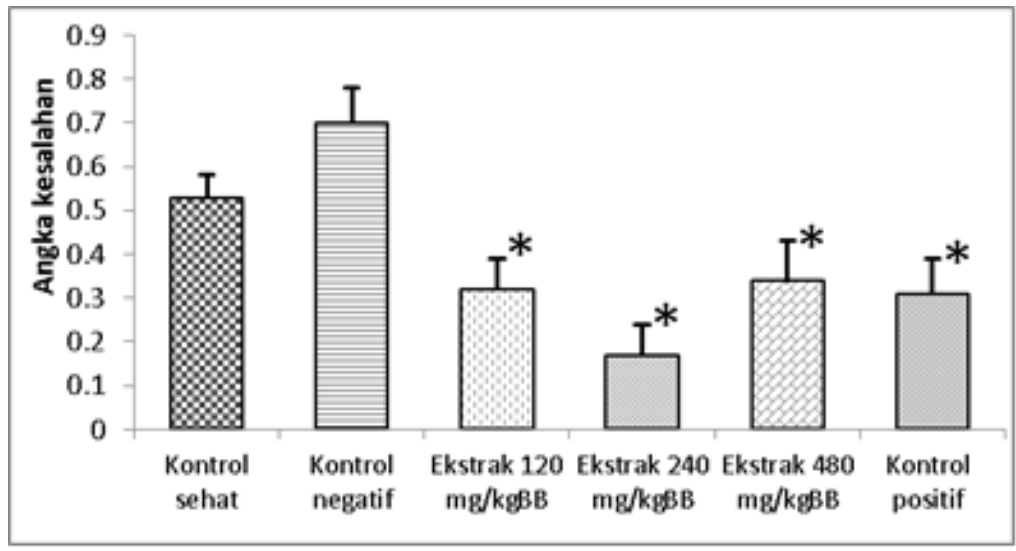

Gambar 2. Histogram angka kesalahan dari semua perlakuan

Keterangan: Tanda $\left(^{*}\right)$ menunjukkan perbedaan bermakna terhadap kelompok kontrol negatif $(\mathrm{p}<0,05)$

Hasil tersebut menjelaskan bahwa kemungkinan kurkumin dalam ekstrak etanol rimpang temulawak dapat menembus sawar darah otak (Smart, 2006) dan memiliki efek neuroprotektif berupa antioksidan
(Chattopaday et al., 2004) terhadap kerusakan otak yang diakibatkan oleh pemberian TMT. Kerusakan itu dapat berupa kematian neuron pada hippocampus yang merupakan komponen penting dalam pembentukan 
memori (Martin et al., 2000). Hal ini sesuai dengan penelitian Walesiuk et al. (2005) bahwa ekstrak yang mengandung antioksidan dapat berfungsi sebagai neuroprotektif yang mampu meminimalkan gangguan memori. Demikian juga dengan Thiyagarajan dan Sharma (2004) yang mengemukakan keberadaan kurkumin sebagai neuroproteksi melalui mekanisme antioksidan akan mencegah kematian sel sehingga gangguangangguan yang diakibatkan kerusakan maupun kematian sel ini dapat dicegah, termasuk kematian sel di hippocampus terkait dengan fungsi memori.

\section{KESIMPULAN}

Ekstrak etanol rimpang temulawak (Curcuma xanthorrhiza Roxb.) dapat mencegah penurunan fungsi memori tikus Wistar yang diinduksi trimetiltin. Dosis 240 mg/kgBB menunjukkan angka kesalahan paling kecil pada uji radial arm maze, namun dosis $120 \mathrm{mg} / \mathrm{kgBB}, 240 \mathrm{mg} / \mathrm{kgBB}$ dan 480 $\mathrm{mg} / \mathrm{kgBB}$ semuanya menunjukkan waktu retensi yang lebih besar pada uji passive avoidance.

\section{DAFTAR PUSTAKA}

Anonim, 2012, Alzheimer's disease facts and figures, Alzheimer's \& Dementia, (8): 131-168.

Butterfield, D.A., Griffin, S., Munch, G., Pasinetti, G.M., 2002, Amyloid $\beta$-peptide and amyloid pathology are central to the oxidative stress and inflammatory cascades under which Alzheimer's disease brain exists, J. Alzheimers Dis., 4 (3): 193 -201.

Chattopaday, I., Biswas, K., Bandyopadhyay, U., Banerjee, R.K., 2004, Turmeric and curcumin: Biological Actions and medicinal applications, Curr. Sci., 87 (1): 44-53.
Colville, T., dan Bassert, J.M., 2002, Clinical Anatomy and Physiology for Veterinary Technicians, 164-193,MOSBY, USA.

Frautschy, S.A., dan Hu, W., 2001, Phenolic anti inflammatory antioxidant reversal of $b$ induced cognitive deficits and neuropathology, Neurobiol Aging, 22: 993-1005.

Herlina, 2010, Pengaruh triterpen total pegagan (Centella asiatica (L) Urban) terhadap fungsi kognitif belajar dan mengingat pada mencit jantan albino (Mus musculus), Jurnal Penelitian Sains, 10:06-06.

Kim, G.Y., Kim, K.H., Lee, S.H., Yoon, M.S., Lee, H.J., Moon, D.O., 2005, Curcumin inhibits immunostimulatory function of dendritic cells: MAPKs and translocation of NF-B as potential targets, J Immunol, 174: 8116-24.

Martin, S.J., Grimwood, P.D., Morris, R.G., 2000, Synaptic plasticity and memory: an evaluation of the hypothesis, Annu. Rev. Neurosci., 23:649-711.

Musalmah, M., Rusdiah, R.J., Noor, A.A.H., 2009, Induction of DNA Damage and Cell Death by Beta Amyloid Peptide and Its Modification by Tocotrienol Rich Fraction (TRF), Med \& Health, 4(1): 815.

Narwanto, M.I., Aswin, S., Mustofa, 2008, Pengaruh pemberian etanol jangka panjang terhadap memori kerja spasial pada tikus, Jurnal Kedokteran Brawijaya, Vol. 14 No.2.

Nurcholis, W., Ambarsari, L., Sari, E.K., Darusman, L.K., 2012, Curcuminoid Contents, Antioxidant and AntiInflammatory Activities of Curcuma xanthorrhiza Roxb. and Curcuma domestica Val. Promising Lines From Sukabumi of Indonesia, Prosiding Seminar Nasional Kimia Unesa, 284-292. 
Shuto, M., Higuchi, K., Sugiyama, C., Yoneyama, M., Kuramoto, N., Nagashima, R., Kawada, K., Ogita, K., 2009, Endogenous and exogenous glucocorticoids prevent trimethyltin from causing neuronal degeneration of the mouse brain in vivo: involvement of oxidative stress pathways, J Pharmacol Sci, 110(4):424-36.

Smart, J., 2006, Curcumin: A Powerful Brain Protection Supplement, Available from: URL:

http://accelerating.org/articles/curcumin. html.

Strub, R. L., dan Black, F. W., 2000, The

Mental Status Examination in neurology 4th ed., F. A. Davis, Philadelphia.
Thiyagarajan, M. dan Sharma, S.S., 2004, Neuroprotective effect of curcumin in middle cerebral artery occlusion induced focal cerebral ischemia in rats, Life Sci., 74: 969-985.

Varadarajan, S., Yatin, S., Aksenova, M., Butterfield, D.A., 2000, Review: Alzheimer's amyloid $\beta$-peptideassociated free radical oxidative stress and neurotoxicity, J. Struct. Biol., 130 (23): $184-208$.

Walesiuk, A., Trofimiuk, E., Braszko, J.J, 2005, Gingko biloba extract diminishes stress-induced memory deficits in rats, Pharmacol Rep, 57:176-87.

Winblad, B., 2005, Piracetam: A Review of Pharmacological Properties and Clinical Uses, CNS Drug Revies, 11(2): 169- 